\title{
Modelling the Effects of Climate Change on Hydroelectric Power in Dokan, Iraq
}

\author{
Petter Pilesjo ${ }^{1}$, Sameer Sadoon Al-Juboori ${ }^{2, ~ * ~}$ \\ ${ }^{1}$ GIS Centre, College of Science, Lund University, Lund, Sweden \\ ${ }^{2}$ Electronic and Control Engineering Dept., Kirkuk Technical College, Kirkuk, Iraq \\ Email address: \\ Petter.Pilesjo@gis.lu.se (P. Pilesjo), sameer.al-juboori@gis.lu.se (S. S. Al-Juboori)
}

\section{To cite this article:}

Petter Pilesjo, Sameer Sadoon Al-Juboori. Modelling the Effects of Climate Change on Hydroelectric Power in Dokan, Iraq. International Journal of Energy and Power Engineering. Special Issue: Modeling and Simulation of Electric Power Systems and Smart Grids. Vol. 5, No.1-2, 2016, pp. 7-12. doi: 10.11648/j.ijepe.s.2016050201.12

\begin{abstract}
Due to shift in the average patterns of weather, climate change became one of the significant development challenges. Hydropower is currently being utilized in more than 150 countries, including 11,000 stations with 27,000 generating units. Increasing attention has been paid to hydropower generation in recent years, because it is renewable energy. Temperature and precipitation effects from global climate change could alter future hydrologic conditions in Iraq and, as a result, future hydropower generation. This is also valid for the Middle East and Iraq. The aim of this study (part1) is to evaluate potential climate change impacts on hydropower in Dokan region, and to recommend various options to maintain optimum required water level to ensure full capacity of electricity generation throughout the year. A simple approach assumes that hydropower systems will reduce generation if water supply reduces, and vice versa. The analysis of the approach was carried out to convert changes in water resource availability to changes in electric hydropower generation. By the year 2050 and based on $12 \mathrm{GCMs}$, electric power generation in Dokan power plant will decrease by 20-40 MW. The other factors such as the site head, the turbine generating capacity and efficiency which were neglected, will be measured, calculated and discussed in part 2
\end{abstract}

Keywords: Climate Change, Hydroelectric, Dokan, Dam, Modeling

\section{Introduction}

One of the great challenges of the 21 st century is climate change. Due to shift in the average patterns of weather, climate change and variability are now becoming one of the significant development challenges. A more variable climate is the expected outcome of increases in atmospheric concentrations of greenhouse gases resulting from human activities. Carbon dioxide (CO2) and many greenhouse gases occur naturally and keep the earth warm. Anthropogenic sources of $\mathrm{CO} 2$ since the industrial revolution, have added greatly to the atmospheric concentrations. Transportation and fossil fuels burning for electricity generation are the frequently cited as major sources. Increased levels of greenhouse gas concentrations over the next century are predicted to cause a significant rise in temperature which are greater than at any time in the past $[1,2]$.

The temperature of global average surface has increased by $0.74 \mathrm{C}^{\circ}$ century. $1990 \mathrm{~s}$ was the warmest decade in the 20 th century, and 1998 was observed as the warmest year. The emission of greenhouse gases is one of the major causes of global warming due to anthropogenic activities. As a result of global warming, climatic variables such as sea level, precipitation and atmospheric moisture, snow cover were observed [3].

\section{Future Climate Prediction}

The temperatures are assumed to rise by $3^{\circ} \mathrm{C}$ by the end of the next century, under present rates of economic and population increase. Simulation physical processes in the atmosphere and oceans predictions of future climate are based on the output of complex numerical Global Circulation Models (GCM's). Together with changes in climate patterns that might reduce rainfall in the Middle East, GCM simulations for the region, indicate higher future temperatures that will increase evapotranspiration. [4]. 


\section{Global Distribution of Hydropower}

In more than 150 countries around the world hydropower is currently being utilized, including 11,000 stations with 27,000 generating units. Europe has the highest installed capacity around $260 \mathrm{GW}$, followed by Eastern Asia, led by China then South America, led by Brazil. In the past few years, China has commissioned significant hydropower capacity, and now exceeds the US as the country with the highest total installed capacity; see Figure $1[5,6]$.

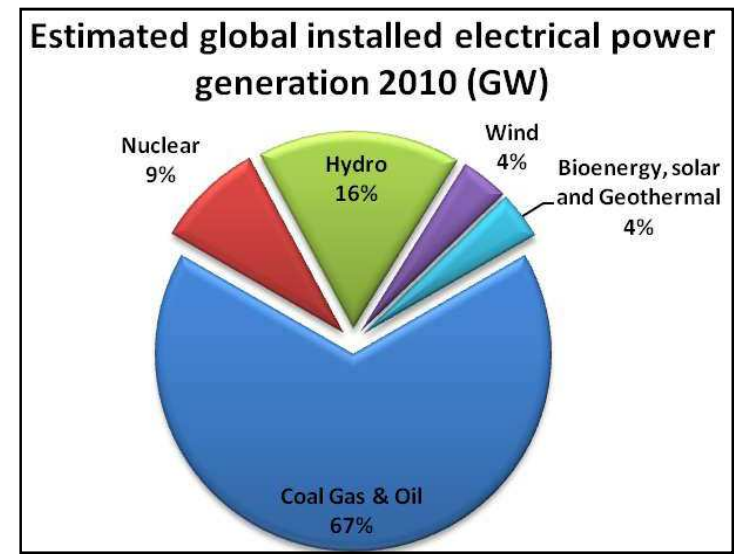

Figure 1. Global Installed Electrical power Capacity $2010(G W)[6]$

To analyze hydropower plants, types, capacities, generation, dams, global water resources, global runoff, rainfall, etc., GIS analysis has been utilized in different countries to understand and visualize regional scenarios of hydropower generation.

\section{The Impacts of Climate Change on Water Resources Modeling}

A range of sensitivities to climate change were displayed by river basins as observed by many studies. It can be seen that increased temperature results in non-linear variations in runoff due to changes in precipitation.

The runoff-rainfall processes non-linear nature will hit hydropower severe by changes in climate given. A reduction in rainfall by $10 \%$ gives a 25 to $50 \%$ loss in hydropower generation. As a result of temperature increase of a few degrees, a severe impact of higher evapotranspiration on hydropower might result in a substantial decrease in generated electricity. In general, increases in climate variability will lead to a lower energy security [7].

The main reason to apply climate models is the ability to explore different scenarios. Scenarios can study aspects that cannot directly be predicted, such climate change and population growth.

The potential for hydroelectric generation approximately follows runoff. A more accurate estimate of climate impacts on hydropower would involve assessment of hydro plants cost, the government's and international organizations policies and the economic development of the country.
A simple hydrological model would be able to derive suitable input-response river flow relationships if given reliable climate and river flow data. Using the suitable technical data and operational parameters, the hydrological model will convert input climate data into estimates of river flows. These results would be processed to estimate the electrical power generated $[4,8]$.

\section{Iraq Electricity Sector Overview}

In Iraq, electricity is supplied by $9.22 \%, 80.49 \%$ and $10.29 \%$ from hydro power, fossil fuel power plants and imported electricity respectively [9].

About 24,400 MW of new capacity will be added due to 2017, including7, $000 \mathrm{MW}$ of thermal power, 13,000 MW of gas-fired, and $400 \mathrm{MW}$ of renewable energy. According to the country's energy master plan, a further 4,000 MW will be added by the conversion of simple-cycle power plants to combined-cycle technology [13].

Because the country is currently more interested in developing power plants in a short duration to get more energy quickly, oil- and gas-fired plants are currently the preferred choice. Although hydropower development is a part of the long term strategy, there is also more focus on developing large dams for flood protection and irrigation. Wind and solar fields are also desired. The full hydropower potential may be estimated as high as $80,000 \mathrm{GWh}$ annually. Table1 shows the installed capacity of hydro power plants in Iraq $[9,10$, and 11].

Table 1. The hydro power plants installed capacity in Iraq, 2012 [9].

\begin{tabular}{lll}
\hline No. & Project name & Installed capacity (MW) \\
\hline 1 & Dokan Dam (our case study) & 400 \\
2 & Darbandikhan Dam & 240 \\
3 & Mosul Main Dam & 750 \\
4 & Mosul Dam pump storage plant & 200 \\
5 & Mosul Regulating Dam & 60 \\
6 & Haditha Dam & 660 \\
7 & Samaraa Barrage & 80 \\
8 & Hemrin Dam & 50 \\
9 & Adhaim Dam & 40 \\
10 & Al-Hindiyah Barrage & 15 \\
11 & Shatt Al-Kuffa Regulator & 6 \\
\hline
\end{tabular}

\section{Dokan Dam in Iraq}

The location of the Dokan Dam is shown in Figure2 and 3 below. It is located in the north of Iraq on the Lesser Zab River approximately $295 \mathrm{~km}$ north of Baghdad and $65 \mathrm{~km}$ southeast of Sulaimaniyah city. The Dokan Dam reservoir had a total design of 6,870 Million Cubic Meters [12, 13]. 


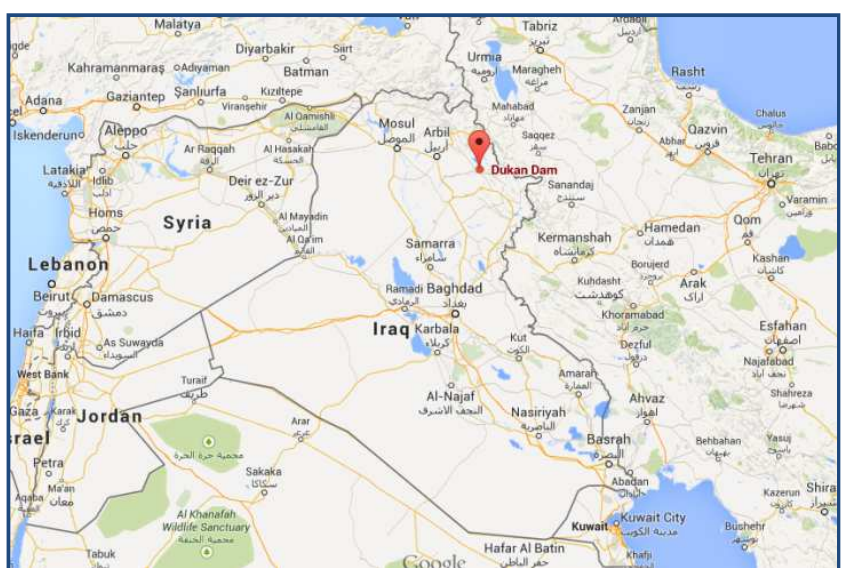

Figure 2. The Dokan Dam is located on the Lesser Zab River [Google Earth].

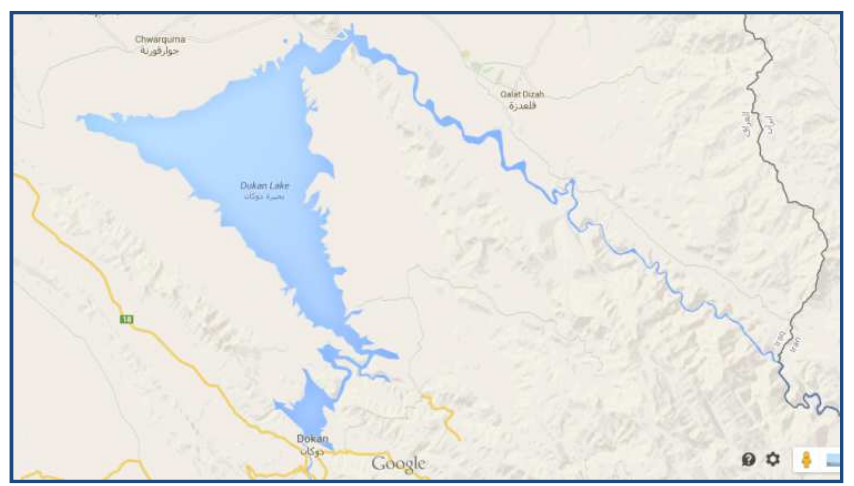

Figure 3. Dokan Lake [Google Earth].

\section{Assessing Climate Change Impacts on Hydropower Generation Systems}

To assess climate change impacts on hydropower generation systems, a simple approach is based on the assumption that the current hydropower generation system may only be limited by water availability and that if water supply reduces, the hydropower systems will reduce generation and vice versa. Hydropower generation with this approach changes in annual mean flows. To simulate observed regional patterns of the twentieth century, multi-decadal changes in stream flow, an ensemble of 12 climate models was used with statistically and significant skill. The hydropower generations by countries as shown in Figure 4, were mapped in a GIS database system [5, 14].

Database management expedites the analysis on various tables that make up the GIS database. Computed future (2050) changes in runoff are based on results from $12 \mathrm{GCMs}$. The future (year 2050) generation based on the current generation levels is produced by mapping the changes as shown in Figure 5.

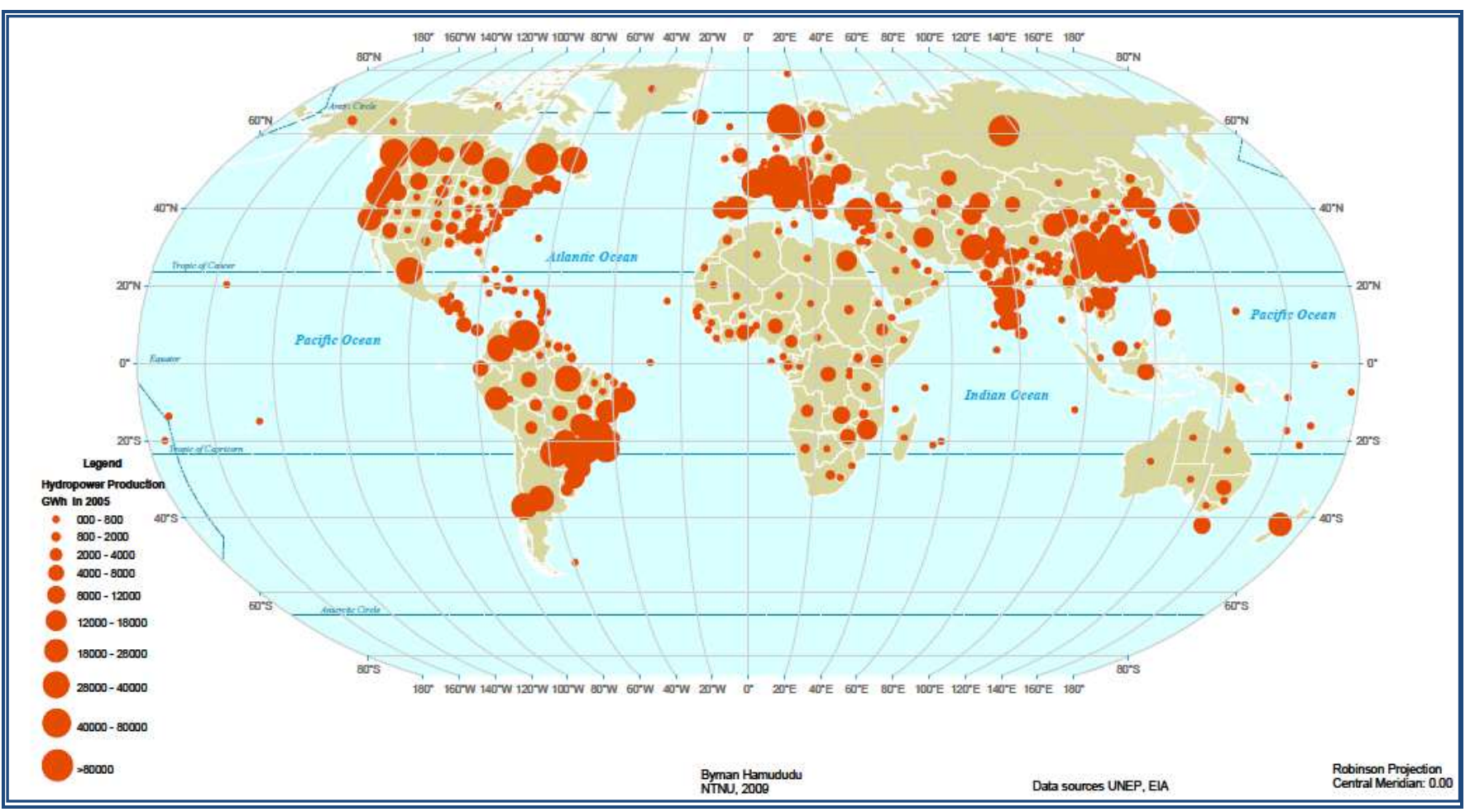

Figure 4. Hydropower generation (GWh) in 2005[14]. 


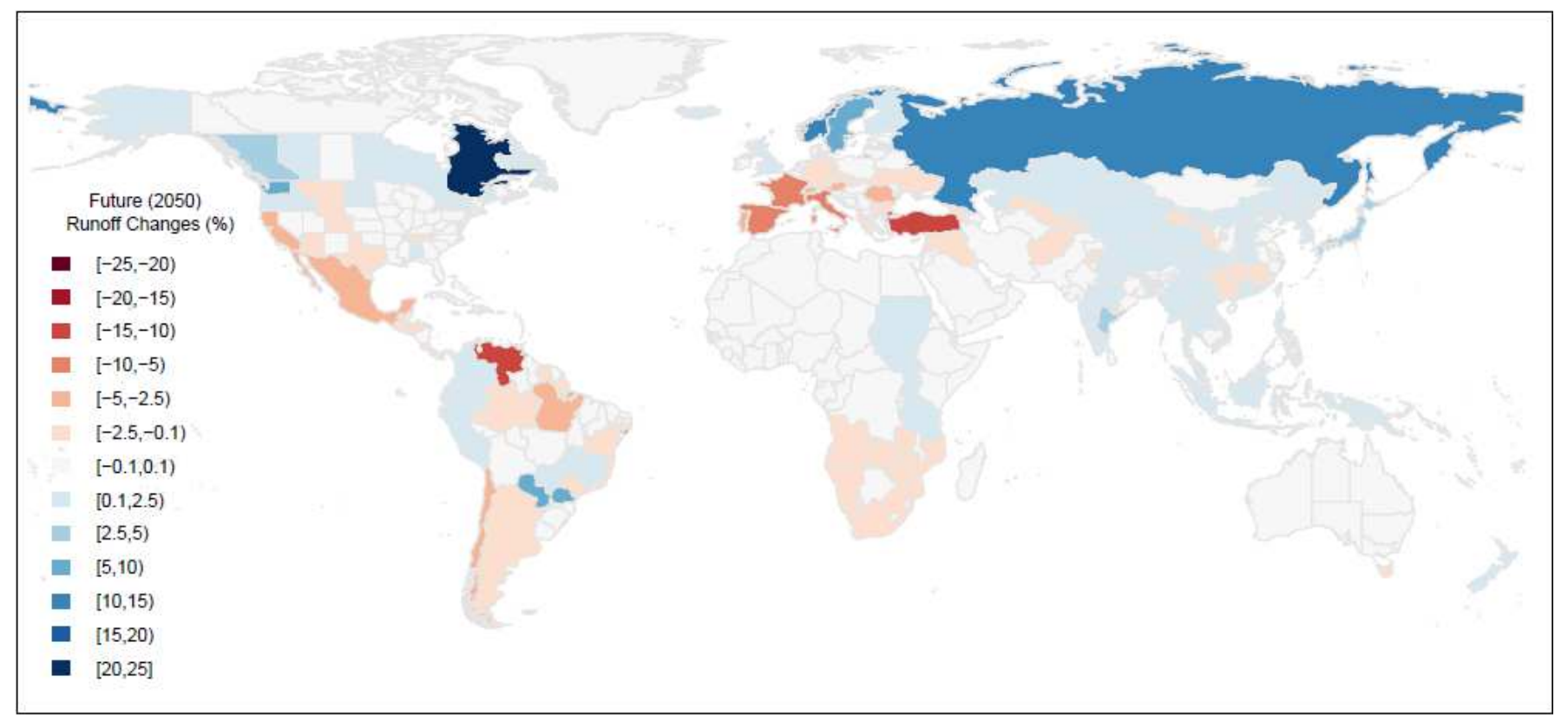

Figure 5. Runoff changes (\%) based on 12 GCMs under A1B scenario for future (2050) [5].

Water resource availability changes are converted to changes in hydropower generation. The runoff was assumed to be the main determinant of limitation to hydropower generation. The analysis methodology is based on the fact that hydropower generation is a function of flow $(Q$, in $\left.\mathrm{m}^{3} \mathrm{~s}-1\right)$, Head ( $\mathrm{H}$, in $\left.\mathrm{m}\right)$ and efficiencies. Assuming that the changes in water resources will impact hydropower produced in the future, the most varying factor used in the procedure for the water resources for each country is the flow (Q [5].

On average, runoff can be thought of as the difference between the precipitation and evaporation over long periods of time, and this makes it the available water to be used for hydropower, domestic consumption, irrigation etc. as shown in Figure 6.

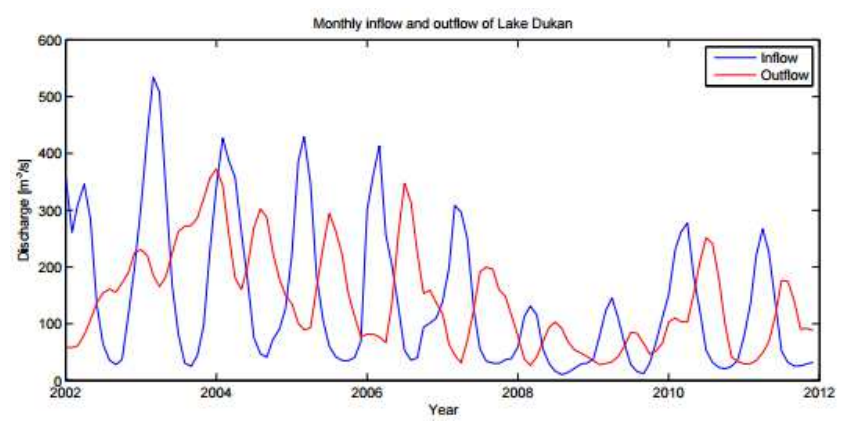

Figure 6. A comparison between Inflow and Outflow of Dokan Lake during $(2002-2012)$ [14].

Compared with control period, Figure 7 shows the average annual rainfall for the north of Iraq for A2 and B2 scenarios. [14]
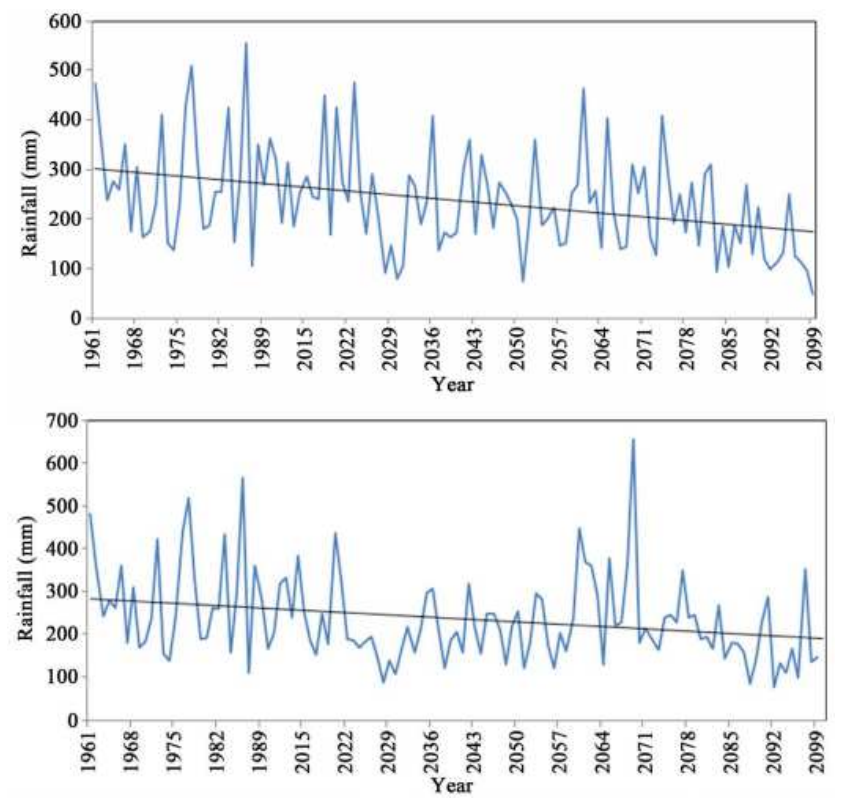

Figure 7. Average annual rainfall in the north of Iraq for A2 scenario (upper) and B2 scenario (lower) compared with control period.

Estimated changes in runoff which are used as predictors in projecting hydropower generation are the bases for country values, GCM estimates. Dokan Dam and Zab River catchment water balance recorded data are shown in Tables2, 3 , and4 [13]. 
Table 2. Rainfall and evaporation water balance in North of Iraq for the period 1970-2011[13].

\begin{tabular}{|c|c|c|c|c|c|c|c|c|c|c|c|c|}
\hline & Jan. & Feb. & Mar. & Apr. & May & June & Jul. & Aug. & Sep. & Oct. & Nov. & Dec. \\
\hline Rain, mm. & 127.3 & 125.3 & 135.9 & 93.1 & 26.9 & & & & & 27.67 & 92.6 & 134.8 \\
\hline $\begin{array}{l}\text { Energy Evaporation } \\
\text { transpiration, } \mathrm{mm}\end{array}$ & 26.95 & 31.76 & 48.60 & 77.0 & 111.65 & 111.65 & 158.33 & 153.04 & 136.19 & 103.47 & 64.97 & 37.53 \\
\hline $\begin{array}{l}\text { Surplus of water, mm. } \\
\text { Water deficit, } \mathrm{mm} \text {. }\end{array}$ & 100.3 & 93.54 & 87.3 & 16.1 & 84.75 & 111.65 & 158.33 & 153.04 & 136.19 & 75.8 & 27.63 & $\begin{array}{l}97.27 \\
-\end{array}$ \\
\hline
\end{tabular}

Table 3. Characteristic for the annual discharge of the Little Zab River in Dokan Dam [13].

\begin{tabular}{lllll}
\hline The year & Properties of the year & $\begin{array}{l}\text { Medium Discharge } \\
\mathbf{m}^{\mathbf{3}} / \mathbf{s e c}\end{array}$ & Annual revenue Billion $\mathbf{m}^{\mathbf{3}}$ & $\begin{array}{l}\text { The average height of the } \\
\text { water basis } \mathbf{~ m m} / \mathbf{y}\end{array}$ \\
\hline $1958-2001$ & General & 193.29 & 6.09 & 812.52 \\
1988 & Wet & 446 & 14.06 & 1896.66 \\
2000 & Dried & 58 & 1.82 & 245.5 \\
1996 & medium & 201 & 6.33 & 853.90 \\
\hline
\end{tabular}

Table 4. Entering and release water rate in the lake (1953-2011). [13].

\begin{tabular}{lll}
\hline Month & Monthly rate of import $\mathbf{~ m}^{3} / \mathbf{s e c}$. & Monthly released discharge rate $\mathbf{~ m}^{\mathbf{3}} / \mathbf{s e c}$. \\
October & 49.38 & 200 \\
November & 110.4 & 175 \\
December & 166.9 & 170 \\
January & 200.8 & 163 \\
February & 327.8 & 176 \\
March & 429 & 209 \\
April & 424.3 & 188 \\
May & 260.1 & 169 \\
June & 114.6 & 162 \\
July & 59.54 & 223 \\
August & 40.65 & 273 \\
September & 39.19 & 245 \\
The annual average $\left(\mathrm{m}^{3} / \mathrm{sec}\right)$ & 184.7 & 196 \\
The annual average $\left(\mathrm{billion}^{3}\right)$ & 5.82 & 6.19 \\
\hline
\end{tabular}

\section{Results and Discussion}

The overall objective of this study was to evaluate the impacts of climate change on hydropower to present a global picture of impacts.

According to recorded data in Figures 7 and 8, a comparison shows a decrease in inflow and outflow of Dokan Lake during $(2002$ - 2012) and the average annual rainfall has been reduces in the north of Iraq for both A2 and B2 scenarios.

A lot of simplifications were made. Only the mean discharge flow has been used as a factor to hydropower generation, while the other factors such as the site head and the turbine generating capacity and efficiency were currently neglected and will be measured, calculated, analyzed and discussed in (part2), a new model will be build.

From the analysis, based on 2005 global hydropower generation presented in Figure 5, it can be seen that by year 2050 , the hydropower generation have totally decreased by $5-10 \%$. Runoff changes in Iraq based on 12 GCMs under A1B scenario, Figure 6 decreases by 5 to $10 \%$ which will have negative effects on energy sector and the future production of electricity in Iraq.

Accordingly hydropower generation reduces by $5-10 \%$ and the electric power generation in Dokan power plant decreases by $20-40 \mathrm{MW}$.

To mitigate the effects of climate change on hydropower plants, improvements in the present hydro-power resources for water recycling and/or development of micro-dams for storage of excess water need exploration.

Finally, construction of new plants with better technology (e.g., high efficiencies) in the hydropower sector could help to reduce the gap that may be created by the effects of climate change on electric power generation.

\section{Conclusions}

Based on this study part1 we conclude that:

1. Some countries will experience decreases in climate potential while others increases, but with a great degree of risks in both cases.

2. It can be concluded that one of the most environmental and social sensitive power generation technologies is hydropower technology.

3. In some countries, careful planning and design are required due to the occurrences of extreme weather events caused by climate change, so as to come up with sustainable hydropower projects.

4. A need for national adaptation strategies to water supply shortages is so important. 


\section{References}

[1] IPCC: Special Report on Renewable Energy Sources and Climate Change Mitigation, Technical Report, Intergovernmental Panel on Climate Change: Geneva, Belgium, 2011.

[2] Subimal, G.; Chaitali M.: Assessing Hydrological Impacts of Climate Change: Modeling Techniques, and Challenges. The Open Hydrology Journal, 4, 115-121 (2010).

[3] Atsushi, I.: Estimating Global Climate Change Impacts On Hydropower Projects: Applications in India, Srilanka And Vietnam, The World Bank Sustainable Development Network Finance, Economics, and Urban Development Department September 2007.

[4] Harrison, G.P.; Whittington, H.W.; Gundry, S.W.: Climate Change Impacts on Hydroelectric Power. In: Proceedings of 33rd University Power Engineering Conference, Edinburgh, 391-394 (1998).

[5] Byman, H.; Aanund, K.: Assessing Climate Change Impacts on Global Hydropower. Energies. 5, 305-322 (2012).

[6] Manjeet, D.: Climate Change Impacts on Reservoir based Hydropower Generation in Nepal: A case study of Kulekhani Hydropower Plant. M.Sc. thesis submitted to School of Environmental Management and Sustainable Development (SchEMS) Baneshwor, Kathmandu September, 2011.
[7] Advait, G.: Climate change impacts on hydropower and the electricity market: A case study for Switzerland Master's Thesis Faculty of Science University of Bern, 2014.

[8] Peter, D.: Climate Change and Hydropower, Impact and Adaptation Costs: Case Study Kenya. Report available at www.futurewater.nl. 2009.

[9] Indexmundi: Electricity Import to Iraq in 2011. Available at www.indexmundi.com/g/g.aspx?v=83\&c=iz\&l=en. 2012.

[10] Milly, P.C.D.; Dunne, K.A.; Vecchia, A.V.: Global pattern of trends in stream flow and water availability in a changing climate. Nature. 438, 347-350 (2005).

[11] Ratcliffe, V.: Power Generation a Top Priority in Iraq. Available www.meed.com/supplements/2012/iraq-projects/power-genera tion-a-top-priority-in-iraq/3129589. article. (2012).

[12] The World Bank: Dokan and Darbandikhan Emergency Project. Inspection Report 1537 (2006).

[13] Iraq Ministry of water resources, Center for the study of water resources projects for the northern region: Evaluation of some irrigation projects in Dukan watershed as controlling and conservation of water resources. Preparing by: Amwag Abbas Talab, Assistant general manager of irrigation and drainage, 2013.

[14] Nadhir, Al-Ansari; Ammar A.; Ali, S.: Present Conditions and Future Challenges of Water Resources Problems in Iraq. J. Water Resour. Prot. 6, 1066-1098 (2014). 